\title{
The effect of tranilast on fibroblast activation protein $\alpha($ FAP- $\alpha)$ expression in normal and keloid fibroblasts in vitro
}

\author{
Wpływ tranilastu na ekspresję białka aktywującego fibroblasty $\alpha$ (FAP- $\alpha$ ) \\ w fibroblastach prawidłowych oraz fibroblastach keloidowych in vitro
}

\author{
Paweł P. Antończak', Magdalena Jurzak', Katarzyna Adamczyk', Agnieszka Garncarczyk', \\ Magdalena Hartman-Petrycka²
}

\begin{abstract}
'Department of Cosmetology, School of Pharmacy with the Division of Laboratory Medicine in Sosnowiec, Medical University of Silesia, Katowice, Poland

2Department of Basic Biomedical Sciences, School of Pharmacy with the Division of Laboratory Medicine in Sosnowiec, Medical University of Silesia, Katowice, Poland
\end{abstract}

\author{
'Zakład Kosmetologii, Katedra Kosmetologii, Wydział Farmaceutyczny z Oddziałem Medycyny Laboratoryjnej w Sosnowcu \\ Śląskiego Uniwersytetu Medycznego w Katowicach, Polska \\ 2Katedra i Zakład Podstawowych Nauk Biomedycznych, Wydział Farmaceutyczny z Oddziałem Medycyny Laboratoryjnej w Sosnowcu \\ Śląskiego Uniwersytetu Medycznego w Katowicach, Polska
}

\section{CORRESPONDING AUTHOR/} ADRES DO KORESPONDENCJI:

Paweł P. Antończak

Zakład Kosmetologii

Katedra Kosmetologii

Śląski Uniwersytet Medyczny

ul. Kasztanowa 3

41-200 Sosnowiec, Polska

tel.: +4832 2699835

faks: +48322699834

e-mail: pantonczak@sum.edu.pl

\begin{abstract}
Introduction. Tranilast ( $\mathrm{N}-\left(3^{\prime}, 4^{\prime}\right.$-demethoxycinnamoyl)-anthranilic acid) is an anti-allergic drug. Its mechanism of action is based on the inhibition of antigen-induced release of chemical mediators from mast cells and basophils. It also reveals antifibroproliferative activities. These properties of tranilast are used in the treatment of hypertrophic scars and keloids. Keloids are characterized by incorrect extracellular matrix components turnover. Fibroblasts derived from keloids reveal overproduction of collagen type I and decreased degradation of extracellular matrix in comparison with normal fibroblasts. Fibroblast activation protein $\alpha(\mathrm{FAP}-\alpha)$ may play an important role in remodeling of extracellular matrix and the invasive properties of keloids.
\end{abstract}

Objective. In the present study, the effect of tranilast on expression of $F A P-\alpha$ gene and its protein was evaluated in normal human dermal fibroblasts and fibroblasts derived from keloids cultured in vitro.

Materials and methods. In the first stage of the study, the influence of tranilast on cell viability was estimated. The second stage of the study included the quantitative evaluation of $F A P-\alpha$ mRNA expression in normal and keloid fibroblasts treated with tranilast. The third stage of the study comprised fibroblast activation protein $\alpha$ expression analysis in the examined cells treated with tranilast.

Results and conclusions. The expression of $F A P-\alpha$ gene and fibroblast activation protein $\alpha$ is higher in keloid fibroblasts. Tranilast at concentrations of $3 \mu \mathrm{M}$ and $30 \mu \mathrm{M}$ up-regulated mRNA FAP- $\alpha$ expression in normal fibroblasts but did not influence keloid fibroblasts. The drug, at concentrations of $30 \mu \mathrm{M}$ and $300 \mu \mathrm{M}$ up-regulated fibroblast activation protein $\alpha$ expression in normal fibroblasts and did not influence keloid fibroblasts. Tranilast antiproliferative effect is not associated with FAP- $\alpha$ expression in keloid fibroblasts. 


\section{STRESZCZENIE}

Wprowadzenie. Tranilast (kwas N-(3',4'-demetoksycynamoilo)-antranilowy) należy do leków przeciwalergicznych. Jego mechanizm działania polega na hamowaniu indukowanego antygenowo wydzielania mediatorów chemicznych z mastocytów i granulocytów zasadochłonnych. Tranilast ma także działanie przeciwfibroproliferacyjne, dlatego stosowany jest w leczeniu blizn przerostowych i keloidów (bliznowców). Keloidy mają związek m.in. z nieprawidłowymi przemianami składników macierzy zewnątrzkomórkowej. Fibroblasty pochodzące z keloidów wykazują nadmierną produkcję kolagenu typu I oraz ograniczony rozkład macierzy zewnątrzkomórkowej w porównaniu z prawidłowymi fibroblastami. Białko aktywujące fibroblasty $\alpha$ (FAP- $\alpha$ ) może odgrywać ważną rolę w przebudowie macierzy zewnątrzkomórkowej i właściwościach inwazyjnych keloidów.

Cel pracy. Ocena wpływu tranilastu na ekspresję genu FAP- $\alpha$ i jego białka w prawidłowych fibroblastach skóry ludzkiej oraz fibroblastach pochodzących z keloidów hodowanych in vitro.

Materiał i metodyka. W pierwszym etapie badań oceniano wpływ tranilastu na przeżywalność komórek. Drugi etap badań obejmował ocenę ilościową ekspresji mRNA FAP- $\alpha$ w fibroblastach prawidłowych oraz fibroblastach keloidowych poddanych działaniu tranilastu. W trzecim etapie badano ekspresję białka aktywującego fibroblasty $\alpha \mathrm{w}$ komórkach poddanych działaniu tranilastu.

Wyniki i wnioski. Ekspresja genu FAP- $\alpha$ i białka aktywującego fibroblasty $\alpha$ jest wyższa w fibroblastach keloidowych. Tranilast w stężeniach $3 \mu \mathrm{M}$ i $30 \mu \mathrm{M}$ nasila ekspresję mRNA FAP- $\alpha$ w prawidłowych fibroblastach, jednak nie wpływa na ekspresję $\mathrm{w}$ fibroblastach keloidowych. Lek w stężeniach $30 \mu \mathrm{M}$ i $300 \mu \mathrm{M}$ wzmaga ekspresję białka aktywującego fibroblasty $\alpha \mathrm{w}$ fibroblastach prawidłowych, jednak nie wpływa na fibroblasty keloidowe. Mechanizm działania przeciwfibroproliferacyjnego nie jest związany z wpływem tranilastu na ekspresję FAP- $\alpha$ w fibroblastach pochodzących z keloidów.

Key words: tranilast, keloid fibroblasts, fibroblast activation protein $\alpha$, FAP- $\alpha$.

Słowa kluczowe: tranilast, fibroblasty keloidowe, białko aktywujące fibroblasty $\alpha$, FAP- $\alpha$.

\section{INTRODUCTION}

Tranilast (Rizaben), a derivative of anthranilic acid (N-(3',4'-demethoxycinnamoyl)-anthranilic acid), is an anti-allergic drug. It blocks degranulation of mast cells and basophils [1,2] and inhibits the release of inflammatory mediators such as histamine, leukotrienes, prostaglandins and platelet-activating factor (PAF), which are produced by mast cells and basophils [3].

Moreover, tranilast reveals anti-fibrotic, anti-proliferative and anti-cancer activities. The drug is successfully used in the treatment of hypertrophic scars and keloids. Because of the lack of effective

\section{WPROWADZENIE}

Tranilast (Rizaben), pochodna kwasu antranilowego (kwasu N-(3',4'-demetoksycynamoilo)-antranilowego), jest lekiem przeciwalergicznym. Blokuje degranulację mastocytów i granulocytów zasadochłonnych [1, 2] oraz hamuje wydzielanie mediatorów zapalnych, m.in. histaminy, leukotrienów, prostaglandyn oraz czynnika aktywującego płytki krwi (PAF), wytwarzanych przez mastocyty i granulocyty zasadochłonne [3].

Tranilast ma ponadto właściwości przeciwfibrotyczne, przeciwproliferacyjne i przeciwnowotworowe. Lek wykazuje skuteczność w leczeniu blizn przerostowych i keloidów. Ze względu na brak skutecznego leczenia 
keloid therapy in Poland, the present study hopefully will be of interest to a wide range of physicians involved in its treatment. The mechanism of antifibrotic action of the drug is not fully understood. Studies suggest that the antifibrotic effect of tranilast relies on collagen synthesis inhibition and inhibition of both transforming growth factor $\beta$ (TGF- $\beta$ ) expression and TGF- $\beta$ action $[1,2,4-6]$.

Keloids arise most often as a result of an abnormal wound healing process and are classified as benign growths of connective tissue tumor [7]. Their formation is a consequence of cutaneous injury and irritation, including trauma, insect bite, surgery, vaccination, skin piercing and acne. Notably, superficial injuries that do not reach the reticular dermis never cause keloids. This suggests that this pathology is due to injury of this skin layer [8]. One of the causes of keloid formation is abnormal extracellular matrix (ECM) turnover (biosynthesis and degradation) during complex and multifactorial healing of wounds [9]. Keloids do not exhibit the characteristics of malignant tumors, but they often grow beyond the original location [10].

Both the formation and growth of keloid requires the participation of proteolytic enzymes involved in remodeling of the ECM $[7,10,11]$. Three major groups of lytic enzymes that degrade the ECM include PA-plasmin, matrix metalloproteinases (MMPs), and a disintegrin and metalloproteinases (ADAMs) [12]. A recently discovered enzymatic protein involved in the formation of keloids is fibroblast activation protein $\alpha(\mathrm{FAP}-\alpha)$. The FAP- $\alpha$ is classified as an integral membrane protein although there is soluble form of this protein us well. It belongs to the small family of serine integral membrane peptidases (SIMPs). These peptidases specifically degrade macromolecules containing proline (e.g. collagens). The FAP- $\alpha$ belongs to the family of prolyl oligopeptidases (S9) and subfamily S9B. The subfamily S9B besides FAP- $\alpha$ includes dipeptidylpeptidase IV (DPPIV/CD26), dipeptidylpeptidase 8 (DPP-8), dipeptidylpeptidase 9 (DPP-9) and non-enzymatic proteins (DPL1, DPL2). Until now FAP- $\alpha$ has been shown to have proteolytic activities of gelatinase, dipeptidyl peptidase and endopeptidase. Its substrate repertoire remains mostly unknown $[13,14]$.

The FAP- $\alpha$ expression is observed in reactive fibroblasts during wound healing, fibrosis, carcinogenesis and some tumor cells [13-15]. In tumors are found mesenchymal cells - carcinoma-associated fibroblasts (CAFs). The CAFs are a heterogeneous population of cells referred to as myofibroblasts. These cells play a similar role to myofibroblasts during wound healing, by generation of a stroma environment supporting cell growth, proliferation and motility. However, during wound healing, when the keloidów w Polsce przedstawione badanie z pewnością zainteresuje lekarzy zajmujących się terapią tego schorzenia. Mechanizm działania przeciwfibrotycznego leku nie jest w pełni poznany. Badania sugerują, że właściwości przeciwfibrotyczne tranilastu wynikają z blokowania syntezy kolagenu oraz hamowania ekspresji i działania transformującego czynnika wzrostu $\beta$ (TGF- $\beta$ ) $[1,2,4-6]$.

Rozwój keloidów jest najczęściej wynikiem nieprawidłowego procesu gojenia rany. Keloidy są sklasyfikowane jako łagodne nowotwory skóry wywodzące się z tkanki łącznej [7]. Powstają w miejscu przerwania ciągłości skóry i podrażnienia, m.in. wskutek urazu, ukąszenia owada, zabiegu chirurgicznego, szczepienia, nakłucia skóry, w przebiegu trądziku. Do rozwoju keloidów nie dochodzi w przypadku urazów powierzchownych, które nie powodują uszkodzenia warstwy siateczkowatej skóry właściwej. Mogłoby to sugerować, że uraz w obrębie tej warstwy skóry jest istotnym czynnikiem w patogenezie keloidów [8]. Jedną z przyczyn rozwoju keloidów są nieprawidłowe przemiany macierzy zewnątrzkomórkowej (ECM) (biosynteza i rozpad) w złożonym i wieloczynnikowym procesie gojenia ran [9]. Keloidy nie mają właściwości nowotworów złośliwych, choć często wykraczają swoim zasięgiem poza pierwotną lokalizację [10].

Zarówno powstawanie, jak i rozrost keloidów wymaga udziału enzymów proteolitycznych, które wpływają na przebudowę ECM [7, 10, 11]. Trzy główne grupy enzymów, które powodują rozkład ECM, to: PA-plazmina, metaloproteinazy macierzy pozakomórkowej (MMP), białka zawierające domenę dezintegryny i metaloproteinazy (ADAMs) [12]. Niedawno odkrytym białkiem enzymatycznym uczestniczącym w powstawaniu keloidów jest białko aktywujące fibroblasty $\alpha$ (FAP- $\alpha$ ). FAP- $\alpha$ jest sklasyfikowane jako integralne białko błonowe, choć występuje również w postaci rozpuszczalnej tego białka. Należy do rodziny integralnych błonowych peptydaz serynowych (SIMP). Peptydazy te wywołują swoisty rozkład makrocząstek zawierających prolinę (np. kolagenów). FAP- $\alpha$ należy do podrodziny S9B rodziny oligopeptydaz prolilowych (S9). Poza FAP- $\alpha$ rodzina S9B obejmuje także: dipeptydylopeptydazę IV (DPPIV/CD26), dipeptydylopeptydazę 8 (DPP-8), dipeptydylopeptydazę 9 (DPP-9) oraz białka nieenzymatyczne (DPL1, DPL2). Dotychczas wykazano, że FAP- $\alpha$ ma właściwości proteolityczne żelatynazy, dipeptydylopeptydazy i endopeptydazy. Zestaw substratów FAP- $\alpha$ jest jednak w większości nieznany [13, 14].

Ekspresję FAP- $\alpha$ obserwuje się w fibroblastach reaktywnych, uczestniczących w procesie gojenia ran, włóknienia, kancerogenezy oraz w niektórych komórkach nowotworowych [13-15]. W nowotworach wykrywa się komórki mezenchymalne - tzw. fibroblasty związane z nowotworem (CAF). CAF stanowią niejednorodną populację komórek określanych jako miofibroblasty. 
process is completed, activated fibroblasts decrease. In contrast, CAFs are perpetually activated and do not revert to a normal phenotype and are resistant to apoptosis. Keloid fibroblasts reflect many characteristics of CAFs. The FAP- $\alpha$ is one of the known markers of wound-healing myofibroblasts, CAFs and keloid fibroblasts [16-18]. It is believed that its enzymatic activity plays a key role in formation of keloids and in their growth beyond the original location $[14,15]$.

The influence of tranilast on FAP- $\alpha$ during ECM remodeling in keloid formation and growth is still unknown.

\section{AIM}

The aim of the study was to evaluate the expression of FAP- $\alpha$ in normal human dermal fibroblasts and fibroblasts derived from keloids treated with tranilast in vitro.

\section{MATERIALS AND METHODS}

\section{Cell culture}

Normal human dermal fibroblasts (NHDF; Clonetics ${ }^{\mathrm{TM}}$ ) and fibroblasts derived from keloid (KEL FIB; ATCC, Manassas, VA, USA) were routinely cultured in Dulbecco's Modified Eagle's Medium (DMEM) with L-glutamine (Sigma Aldrich; St. Louis, USA) supplemented with 10\% fetal bovine serum (FBS, GibcoBRL; Rockville, MD, USA) and $100 \mathrm{U} / \mathrm{ml}$ penicillin and streptomycin (Sigma Aldrich; St. Louis, USA). Cells were grown at $37^{\circ} \mathrm{C}, 95 \%$ humidity and $5 \% \mathrm{CO}_{2}$. At confluence, cells were routinely passaged using $1 \times$ trypsin with EDTA (Sigma Aldrich; St. Louis, USA). In the study cells from passages 4 to 6 were used. Both normal and keloid fibroblasts were treated with tranilast (Sigma Aldrich; St. Louis, USA) at $300 \mu \mathrm{M}, 30 \mu \mathrm{M}$ and $3 \mu \mathrm{M}$. Control cells were normal dermal fibroblasts and keloid fibroblasts untreated with tranilast.

\section{Viability analysis of cells treated with tranilast}

The viability of cells treated and untreated with tranilast was assayed using the spectrophotometric method with Cell Proliferation Reagent WST-1 (Roche Diagnostics GmbH; Mannheim, Germany). Cells were seeded in 96-well microplates at a density of 5000 cells per well. After $24 \mathrm{~h}$ when cells adhered and started growth the medium was replaced with medium supplemented with tranilast. Cells were incubated with the drug for $72 \mathrm{~h}$ under standard culture condition $\left(37^{\circ} \mathrm{C}, 5 \% \mathrm{CO}_{2}\right.$ and $95 \%$
Komórki te odgrywają rolę zbliżoną do miofibroblastów w gojeniu ran poprzez tworzenie środowiska stromalnego sprzyjającego wzrostowi komórek, proliferacji i ruchliwości komórek. Po zakończeniu procesu gojenia ran następuje ograniczenie aktywowanych fibroblastów. W przeciwieństwie do nich CAF są ciągle w stanie aktywacji. Nie powracają do normalnego fenotypu i są odporne na proces apoptozy. Fibroblasty keloidowe mają wiele cech charakterystycznych dla CAF. FAP- $\alpha$ jest jednym ze znanych markerów miofibroblastów, CAF oraz fibroblastów keloidowych występujących podczas gojenia ran [16-18]. Uważa się, że jego aktywność enzymatyczna odgrywa ważną rolę w powstawaniu keloidów i ich rozroście poza obszar pierwotnej lokalizacji [14, 15].

Wpływ tranilastu na FAP- $\alpha$ podczas remodelowania ECM w procesie tworzenia i rozrostu keloidów nie został dotąd wyjaśniony.

\section{CEL PRACY}

Celem badania była ocena ekspresji FAP- $\alpha$ w prawidłowych fibroblastach skóry ludzkiej oraz w fibroblastach pochodzących z bliznowców poddanych działaniu tranilastu in vitro.

\section{MATERIA I I METODYKA}

\section{Hodowla komórkowa}

Prawidłowe fibroblasty skóry ludzkiej (NHDF; Clonetics ${ }^{\mathrm{TM}}$ ) oraz fibroblasty pozyskane z keloidów (KEL FIB; ATCC, Manassas, VA, USA) poddano rutynowej hodowli na podłożu DMEM (Dullbecco’s Modified Eagle's Medium) z dodatkiem L-glutaminy (Sigma Aldrich; St. Louis, USA), wzbogaconym 10\% płodowej surowicy bydlęcej (FBS, GibcoBRL; Rockville, MD, USA) oraz $100 \mathrm{U} / \mathrm{ml}$ penicyliny i streptomycyny (Sigma Aldrich; St. Louis, USA). Komórki hodowano w temperaturze $37^{\circ} \mathrm{C}$ przy wilgotności $95 \%$ i zawartości $\mathrm{CO}_{2} 5 \%$. Po osiągnięciu konfluencji komórki poddano standardowemu pasażowaniu przy wykorzystaniu trypsyny $(1 \times)$ z dodatkiem EDTA (Sigma Aldrich; St. Louis, USA). W badaniu wykorzystano komórki z pasaży 4-6. Zarówno fibroblasty prawidłowe, jak i keloidowe poddano działaniu tranilastu (Sigma Aldrich; St. Louis, USA) w stężeniach $300 \mu \mathrm{M}, 30 \mu \mathrm{M}$ i $3 \mu \mathrm{M}$. Jako komórki kontrolne wykorzystano prawidłowe fibroblasty skóry ludzkiej oraz fibroblasty keloidowe, które nie zostały poddane działaniu tranilastu.

\section{Analiza przeżywalności komórek poddanych działaniu tranilastu}

Przeżywalność komórek, które poddano działaniu tranilastu, oraz tych, które nie miały styczności z lekiem, badano metodą spektrofotometryczną przy 
humidity). The WST-1 test was run according to the manufacturer's protocol. The absorbance was measured $(\lambda=440 \mathrm{~nm})$ using the UVM340 microplate reader (Biogenet).

\section{Analysis of gene expression}

The cells were seeded at a density of 5000 cells per well. After 24-hour incubation under standard culture conditions, the culture medium was replaced with medium with tranilast at $3 \mu \mathrm{M}$, $30 \mu \mathrm{M}$ and $300 \mu \mathrm{M}$. The medium of control cells was replaced with standard medium (DMEM supplemented with $10 \%$ FBS and antibiotics). FAP- $\alpha$ gene expression analysis was performed after 72hour cell incubation with the drug.

\section{RNA extraction}

Total RNA was extracted from the cells with TRIZOL ${ }^{\circledR}$ Reagent (Invitrogen, Carlsbad, CA, USA) according to the manufacturer's protocol. All RNA extracts were treated with DNase I (MBI Fermentas) according to the manufacturer's instructions. RNA concentration was determined spectrophotometrically using Gene Quant II RNA/DNA Calculator (Pharmacia Biotech, USA).

\section{Primers}

Primers specific for FAP- $\alpha$ (GenBank accession no. NM_004460) were designed using Primer Expresso v.2.0 software (PE Applied Biosystems, USA): FAP $\alpha$ forward 5'-CACAgCAAgTTTCAgCgACTACgCCAA-3' and $F A P \alpha$ reverse 5'-TCAgTgCgTCCATCATgAAgggTgg-3' (length of amplicon: $93 \mathrm{bp})$.

\section{Real-time quantitative polymerase chain reaction ( $R T-Q P C R)$ assay}

Transcriptional activity of $F A P-\alpha$ was evaluated as the copy number of RNA per $1 \mu \mathrm{g}$ of total RNA using the RT-QPCR technique with SYBR Green I chemistry (SYBR Green Quantitect RT-PCR Kit, QIAGEN, Valencia, CA, USA). The analysis was carried out using a DNA Engine Opticon Sequence Detector (MJ Research, USA). The RT-QPCR assay was performed in triplicate for each sample.

A commercially available fragment of the $\beta$-actin gene (TaqMan Template Reagent, Applied Biosystems) was used as an external standard necessary to determine absolute gene expression. The fragment of the $\beta$-actin gene was amplified simultaneously with the samples in five concentrations: 0.6 ; $1.2 ; 3.0 ; 6.0 ; 12.0 \mathrm{ng} / \mu \mathrm{l}$ (1 ng of DNA parallels 333 equivalents of gene copies) and a standard curve (plot of CT values/crossing points of different standard dilutions against log of amount of stand- wykorzystaniu odczynnika do badania proliferacji komórek Cell Proliferation Reagent WST-1 (Roche Diagnostics GmbH; Mannheim, Niemcy). Komórki wysiano na mikropłytki 96-dołkowe z gęstością 5000 komórek na dołek. Po upływie 24 godzin, gdy komórki przyczepiły się dna naczynia i podjęły wzrost, podłoże wymieniono na wzbogacone tranilastem. Komórki inkubowano z lekiem przez 72 godziny w standardowych warunkach hodowlanych $\left(37^{\circ} \mathrm{C}\right.$, $5 \% \mathrm{CO}_{2}$ i wilgotność 95\%). Test WST-1 przeprowadzono zgodnie z protokołem producenta. Pomiar absorbancji $(\lambda=440 \mathrm{~nm}$ ) wykonano $\mathrm{z}$ wykorzystaniem czytnika mikropłytek UVM340 (Biogenet).

\section{Analiza ekspresji genów}

Komórki wysiano do dołków (gęstość 5000 komórek/dołek). Po 24-godzinnej inkubacji w standardowych warunkach hodowlanych podłoże wymieniono na wzbogacone tranilastem w stężeniach $3 \mu \mathrm{M}, 30 \mu \mathrm{M}$ i $300 \mu \mathrm{M}$. Podłoże komórek kontrolnych wymieniono na podłoże standardowe (DMEM wzbogacone 10\% FBS i antybiotykami). Analizę ekspresji genu FAP- $\alpha$ przeprowadzono po 72-godzinnej inkubacji z lekiem.

\section{Ekstrakcja RNA}

Ekstrakcję RNA całkowitego z komórek przeprowadzono przy użyciu odczynnika TRIZOL ${ }^{\circledR}$ (Invitrogen, Carlsbad, CA, USA) zgodnie z protokołem producenta. Wszystkie ekstrakty RNA poddano działaniu DNazy I (MBI Fermentas) zgodnie z zaleceniami producenta. Stężenie RNA oznaczono spektrofotometrycznie za pomocą kalkulatora Gene Quant II RNA/DNA (Pharmacia Biotech, USA).

\section{Startery}

Startery dla mRNA FAP- $\alpha$ (numer akcesyjny GenBank: NM_004460) opracowano z wykorzystaniem oprogramowania Primer Expresso v. 2.0 (PE Applied Biosystems, USA): FAP $\alpha$ forward 5'-CACAgCAAgTTTCAgCgACTACgCCAA-3' i FAP $\alpha$ reverse 5'-TCAgTgCgTCCATCATgAAgggTgg-3' (długość amplikonu: $93 \mathrm{pz}$ ).

\section{Analiza metodą ilościowej reakcji łańcuchowej polimerazy w czasie rzeczywistym (RT-QPCR)}

Aktywność transkrypcyjną $F A P-\alpha$ oceniano na podstawie liczby kopii RNA na $1 \mu \mathrm{g}$ RNA całkowitego metodą ilościowej reakcji łańcuchowej polimerazy w czasie rzeczywistym (RT-QPCR) z wykorzystaniem barwnika SYBR Green I (SYBR Green Quantitect RT-PCR Kit, QIAGEN, Valencia, CA, USA). Analizę przeprowadzono za pomocą detektora sekwencji DNA Engine Opticon Sequence Detector (MJ Research, USA). Oznaczenie metodą RT-QPCR wykonano w trzech powtórzeniach dla każdej z próbek badanych. 
ard) was generated. Comparing the CT of unknown amounts of the targets with the standard curve allowed calculation of the initial amount of the targets used in RT-PCR.

The specificity of the RT-PCR reaction for analyzed genes was confirmed by determination of amplimer melting temperature and polyacrylamide gel electrophoresis (PAA).

\section{ELISA assay}

FAP- $\alpha$ protein amount in cell lysates of both lines was evaluated using the enzyme-linked immunosorbent assay (ELISA). For this purpose the cells were seeded in 96-well dishes at a density of 10000 cells per well. After 24-hour incubation under standard culture conditions, the culture medium was replaced with medium with tranilast at concentrations of $3 \mu \mathrm{M}, 30 \mu \mathrm{M}$ and $300 \mu \mathrm{M}$. After $72 \mathrm{~h}$ of treatment, cell culture supernatants were removed and cell cultures were lysed with CelLytic M (Sigma Aldrich; St. Louis, USA) according to the manufacturer's protocol. The protein expression was evaluated using a FAP- $\alpha$ kit according to the manufacturer's protocol (RayBio ${ }^{\circledR}$ ). The measurement of absorbance was performed at a wavelength of $450 \mathrm{~nm}$ using a 340 UVM ASYS reader (Biogenet). The concentration of FAP- $\alpha$ in samples was determined by comparing O.D. of the samples to the standard curve.

\section{Statistical analysis}

The results were subjected to routine statistical analysis using the computer program Statistica PL 8.0. (Stat Soft Inc., Tulsa, OK, USA) with the significance level set at $p<0.05$. Student's $t$-test, ANOVA and Dunnett's test were applied. The results were expressed as the mean \pm standard deviation.

\section{RESULTS}

\section{Cell viability}

In the study, cell viability after 72-hour incubation with tranilast was investigated. There was a trend for higher viability of control keloid fibroblasts compared to control normal fibroblasts ( $p=0.055$; Student's $t$-test). Keloid fibroblasts were characterized by higher viability. Viability of normal fibroblasts and keloid fibroblasts treated with tranilast was compared with viability of control normal and keloid fibroblasts (100\%), respectively (Fig. 1). Viability of normal fibroblasts treated with the drug at $3 \mu \mathrm{M}$, $30 \mu \mathrm{M}$ and $300 \mu \mathrm{M}$ showed significant differences $(p<0.01, p<0.01$ and $p<0.001$ respectively; Dunnett's test). The viability of normal fibroblasts treated
Komercyjnie dostępny fragment genu $\beta$-aktyny (TaqMan Template Reagent, Applied Biosystems) wykorzystano jako wzorzec zewnętrzny niezbędny do oznaczenia bezwzględnej ekspresji genów. Fragment genu $\beta$-aktyny poddano amplifikacji jednocześnie z próbkami w pięciu stężeniach: 0,6, 1,2, 3,0, 6,0 i 12,0 ng/ $\mu \mathrm{l}$ (1 ng DNA odpowiada 333 ekwiwalentom genomu). Następnie wykreślono krzywą wzorcową (nanosząc wartości CT/punkty przecięcia poszczególnych rozcieńczeń wzorcowych w stosunku do log ilości wzorca). Porównanie CT nieznanych ilości genów docelowych z krzywą wzorcową umożliwiło obliczenie początkowej ilości genów docelowych w RT-PCR.

Potwierdzono również swoistość reakcji RT-PCR względem analizowanych genów, oznaczając temperaturę topnienia amplimerów oraz przeprowadzając elektroforezę białek w żelu poliakrylamidowym (PAA).

\section{Test ELISA}

Ilość białka FAP- $\alpha$ w lizatach komórek obu linii oceniano przy wykorzystaniu testu immunoenzymatycznego (ELISA). W tym celu komórki wysiano na 96-dołkowe płytki z gęstością 10000 komórek na dołek. Po 24-godzinnej inkubacji w standardowych warunkach podłoże hodowlane wymieniono na wzbogacone tranilastem w stężeniach $3 \mu \mathrm{M}, 30 \mu \mathrm{M}$ i $300 \mu \mathrm{M}$. Po upływie 72 godzin zebrano supernatanty hodowlane, a hodowle komórkowe poddano lizie przy wykorzystaniu odczynnika CelLytic M (Sigma Aldrich; St. Louis, USA) zgodnie z protokołem producenta. Ekspresję białka oceniano za pomocą zestawu do wykrywania FAP- $\alpha$ zgodnie z protokołem producenta $\left(\right.$ RayBio $\left.^{\circledR}\right)$. Pomiary absorbancji przeprowadzono przy długości fali 450 nm, wykorzystując czytnik 340 UVM ASYS (Biogenet). Stężenie FAP- $\alpha$ w próbkach wyznaczono poprzez porównanie gęstości optycznych próbek z krzywą wzorcową.

\section{Analiza statystyczna}

Uzyskane wyniki poddano rutynowej analizie statystycznej z wykorzystaniem programu komputerowego Statistica PL 8.0. (Stat Soft Inc., Tulsa, OK, USA). Przyjęto poziom istotności statystycznej $p<0,05$. Wykorzystano test $t$-Studenta, ANOVA i test Dunnetta. Wyniki wyrażono $\mathrm{w}$ postaci średniej \pm odchylenie standardowe (SD).

\section{WYNIKI}

\section{Przeżywalność komórek}

W badaniu oceniano przeżywalność komórek po 72-godzinnej inkubacji z dodatkiem tranilastu. Stwierdzono tendencję do wzrostu przeżywalności kontrolnych fibroblastów keloidowych w porównaniu z kontrolnymi fibroblastami prawidłowymi ( $p=0,055$; test $t$-Studenta). Fibroblasty keloidowe cechowały się 


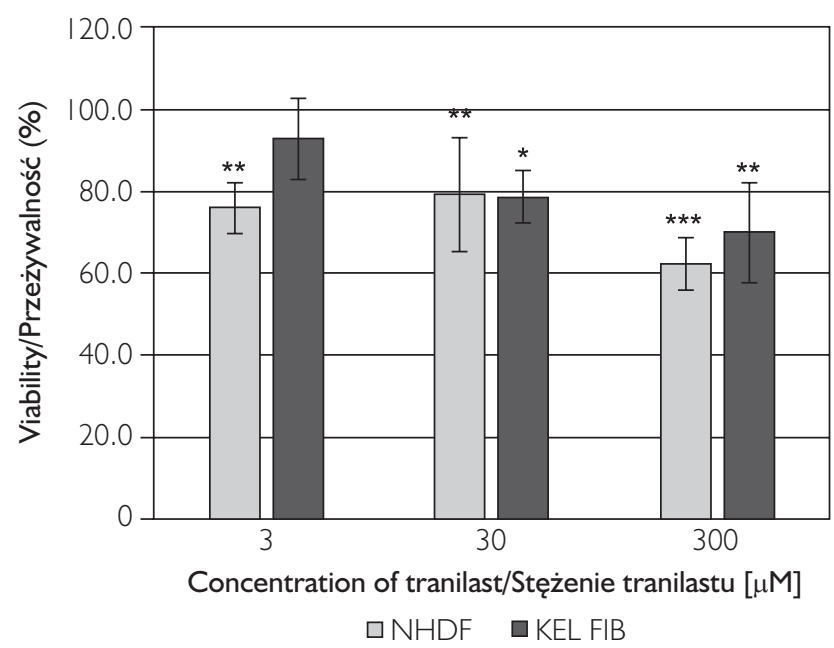

Figure I. Viability of normal and keloid fibroblasts treated with tranilast compared with viability of control cells (as $100 \%$ viability) after 72 h incubation (Student's t-test: $p=0.055$; Dunnett's test: ${ }^{*} p<0.05$; $* * 0.0$ l; $* * * p<0.00$ I)

Rycina I. Przeżywalność fibroblastów prawidłowych oraz fibroblastów pochodzących z keloidów poddanych działaniu tranilastu wyrażona jako odsetek komórek kontrolnych po 72 godzinach inkubacji (test t-Studenta: ${ }^{+} p=0,055$; test Dunnetta: ${ }^{*} p<0,05$; ${ }^{*}$ * $p<0,0$ l; ${ }^{* * *}$ * $<<0,00$ I)

with tranilast was significantly lower (Fig. 1). Tranilast also significantly reduced the viability of keloid fibroblasts at concentrations of $30 \mu \mathrm{M}$ and $300 \mu \mathrm{M}$ $(p<0.05$ and $p<0.01$ respectively; Dunnett's test).

\section{Fibroblast activation protein $\alpha$ mRNA expression}

Expression of FAP- $\alpha$ mRNA in normal and keloid fibroblasts treated with tranilast using real-time QRT-PCR technique was determined after $72 \mathrm{~h}$ of cells' incubation with the drug at concentrations of $3 \mu \mathrm{M}, 30 \mu \mathrm{M}$ and $300 \mu \mathrm{M}$. Specificity of RT-PCR for the target genes was experimentally confirmed by $8 \%$ PAA electrophoresis and amplimer melting temperatures analysis. For the RT-PCR product of $F A P-\alpha$ a single peak in melting curve analysis was obtained at the expected temperatures $\left(80.4^{\circ} \mathrm{C}\right)$. Gel electrophoresis revealed the presence of single products of the predicted size of FAP- $\alpha$ (93 bp). The mRNA for FAP- $\alpha$ was detected in all tested samples. Transcriptional activity of the examined gene was presented as the copy number of mRNA related to $1 \mu \mathrm{g}$ of total RNA.

The expression of FAP- $\alpha$ mRNA showed significant differences between normal fibroblasts and keloid fibroblasts untreated with tranilast $(p=0.0053$; Student's $t$-test). The expression of FAP- $\alpha$ mRNA in keloid fibroblasts was higher $\left(2.53 \pm 0.24 \times 10^{4}\right)$ than in normal fibroblasts $\left(1.73 \pm 0.58 \times 10^{3}\right)$ (Fig. 2).

The expression of FAP- $\alpha$ mRNA showed significant differences between control normal fibroblasts and normal fibroblasts treated with tranilast at $3 \mu \mathrm{M}(p<0.0001$; Dunnett's test $)$ and $30 \mu \mathrm{M}$ $(p<0.0001$; Dunnett's test). The drug significantly up-regulated the expression of FAP- $\alpha$ mRNA wyższą przeżywalnością. Przeżywalność prawidłowych i keloidowych fibroblastów poddanych działaniu tranilastu porównano odpowiednio z przeżywalnością prawidłowych i keloidowych fibroblastów kontrolnych (100\%) (ryc. 1). Przeżywalność prawidłowych fibroblastów poddanych działaniu leku w stężeniach $3 \mu \mathrm{M}$, $30 \mu \mathrm{M} \mathrm{i} 300 \mu \mathrm{M}$ wykazała istotne różnice (odpowiednio $p<0,01, p<0,01$ i $p<0,001$; test Dunnetta). Przeżywalność prawidłowych fibroblastów poddanych działaniu tranilastu była istotnie niższa (ryc. 1). Tranilast ograniczał również istotnie przeżywalność fibroblastów keloidowych w stężeniach $30 \mu \mathrm{M}$ i $300 \mu \mathrm{M}$ (odpowiednio $p<0,05$ i $p<0,01$; test Dunnetta).

\section{Ekspresja mRNA białka aktywującego fibroblasty $\alpha$}

Ekspresję mRNA FAP- $\alpha$ w prawidłowych i keloidowych fibroblastach poddanych działaniu tranilastu oceniano metodą QRT-PCR w czasie rzeczywistym po 72-godzinnej inkubacji komórek z dodatkiem leku w stężeniach $3 \mu \mathrm{M}, 30 \mu \mathrm{M}$ i $300 \mu \mathrm{M}$. Swoistość metody RT-PCR względem genów docelowych potwierdzono doświadczalnie na podstawie elektroforezy białek w 8-procentowym żelu poliakrylamidowym (PAA) oraz analizy temperatur topnienia amplimerów. Dla produktu RT-PCR FAP- $\alpha \mathrm{w}$ analizie krzywej topnienia stwierdzono pojedynczy pik w oczekiwanej temperaturze $\left(80,4^{\circ} \mathrm{C}\right)$. Elektroforeza żelowa wykazała obecność pojedynczych produktów o przewidywanej wielkości FAP- $\alpha$ (93 pz). We wszystkich badanych próbkach wykryto mRNA FAP- $\alpha$. Aktywność transkrypcyjną badanego genu określono jako liczbę kopii mRNA przypadających na $1 \mu \mathrm{g}$ RNA całkowitego.

Wykazano istotne różnice w ekspresji mRNA FAP- $\alpha$ między prawidłowymi a keloidowymi fibroblastami 


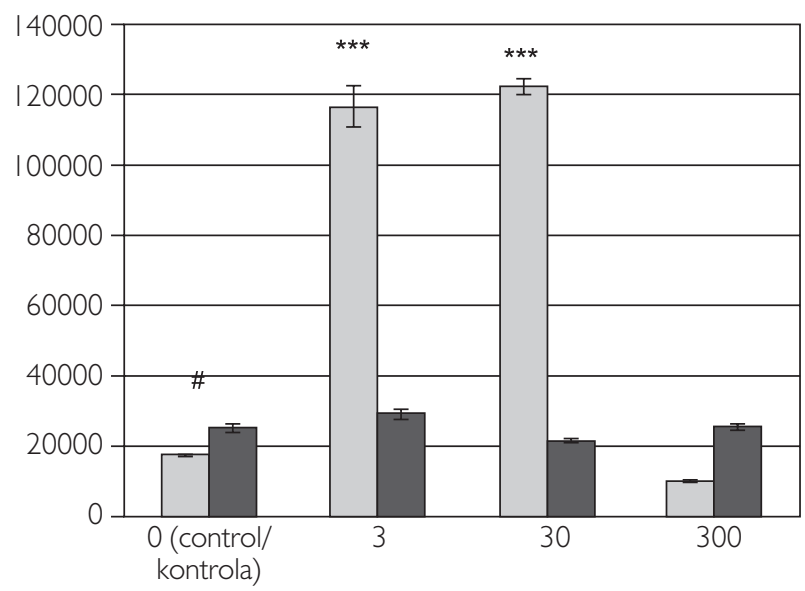

Concentration of tranilast/Stężenie tranilastu [ $\mu \mathrm{M}]$

$\square$ NHDF $\quad$ KEL FIB

Figure 2. Results of FAP- $\alpha$ mRNA expression in normal and keloid fibroblasts treated with tranilast (Student's t-test: \# $p<0.0$ l; Dunnett's test: $* * * * 0.001$ ).

Rycina 2. Wyniki ekspresji mRNA FAP- $\alpha$ w fibroblastach prawidłowych oraz fibroblastach pochodzących z keloidów poddanych dziataniu tranilastu (test t-Studenta: ${ }^{\#} p<0,0$ I; test Dunnetta: ${ }^{*} * * * 0,00$ I)

in normal fibroblasts. However, the expression of $F A P-\alpha$ mRNA did not show significant differences between control keloid fibroblasts and keloid fibroblasts treated with tranilast $(3 \mu \mathrm{M}: p=0.1914$; $30 \mu \mathrm{M}: p=0.1638$ and $300 \mu \mathrm{M}: p=0.9999$; Dunnett's test) (Fig. 2).

\section{Fibroblast activation protein $\alpha$ expression}

The expression of FAP- $\alpha$ protein also showed significant differences between control normal and keloid fibroblasts $(p<0.0001$; Student's $t$-test). The expression of $F A P-\alpha$ in keloid fibroblasts was higher $(1795 \pm 195.5 \mathrm{pg} / \mathrm{ml})$ than in normal fibroblasts (1056.2 $\pm 111.1 \mathrm{pg} / \mathrm{ml}$ ) (Fig. 3).

The expression of FAP- $\alpha$ protein showed significant differences between control normal and normal fibroblasts treated with tranilast at $3 \mu \mathrm{M}, 30 \mu \mathrm{M}$, $300 \mu \mathrm{M}(p<0.001$ and $p<0.001$ respectively; Dunnett's test). The expression of FAP- $\alpha$ did not show significant differences between control keloid fibroblasts and keloid fibroblasts treated with tranilast (Fig. 3).

\section{DISCUSSION}

Tranilast is considered as a selective collagen synthesis inhibitor and is used as an anti-fibroproliferative agent in therapy of keloids and hypertrophic scars. However, the exact mechanism of antifibrotic action of tranilast is still unknown. niepoddanymi działaniu tranilastu $(p<0,0053$; test $t$-Studenta). Ekspresja mRNA FAP- $\alpha$ w fibroblastach keloidowych była wyższa $\left(2,53 \pm 0,24 \times 10^{4}\right)$ niż $w$ fibroblastach prawidłowych $\left(1,73 \pm 0,58 \times 10^{3}\right)$ (ryc. 2).

Stwierdzono istotne różnice $\mathrm{w}$ ekspresji mRNA $F A P-\alpha$ między prawidłowymi i keloidowymi fibroblastami kontrolnymi poddanymi działaniu tranilastu w stężeniu $3 \mu \mathrm{M}$ ( $p<0,0053$; test Dunnetta) i $30 \mu \mathrm{M}(p<0,0001$; test Dunnetta). Lek istotnie nasilał ekspresję mRNA FAP- $\alpha$ w prawidłowych fibroblastach. Nie wykazano jednak istotnych różnic w zakresie ekspresji mRNA FAP- $\alpha$ między kontrolnymi fibroblastami keloidowymi a fibroblastami keloidowymi poddanymi działaniu tranilastu ( $3 \mu \mathrm{M}: p=0,1914 ; 30 \mu \mathrm{M}: p=0,1638$ i $300 \mu \mathrm{M}: p=0,9999$; test Dunnetta) (ryc. 2).

\section{Ekspresja białka aktywującego fibroblasty $\alpha$}

Istotne różnice w ekspresji białka FAP- $\alpha$ wykazano również między prawidłowymi i keloidowymi fibroblastami kontrolnymi ( $p<0,0001$; test $t$-Studenta). Ekspresja FAP- $\alpha$ w fibroblastach keloidowych była wyższa (1795 $\pm 195,5$ pg/ml) niż w fibroblastach prawidłowych (1056,2 $\pm 111,1 \mathrm{pg} / \mathrm{ml}$ ) (ryc. 3).

Pod względem ekspresji białka FAP- $\alpha$ stwierdzono istotne różnice między prawidłowymi fibroblastami kontrolnymi a prawidłowymi fibroblastami poddanymi działaniu tranilastu w stężeniach $3 \mu \mathrm{M}$, $30 \mu \mathrm{M}$ i $300 \mu \mathrm{M}$ (odpowiednio $p<0,001$ i $p<0,001$; test Dunnetta). Nie wykazano natomiast istotnych różnic w ekspresji FAP- $\alpha$ pomiędzy kontrolnymi fibroblastami keloidowymi a fibroblastami keloidowymi poddanymi działaniu tranilastu (ryc. 3). 


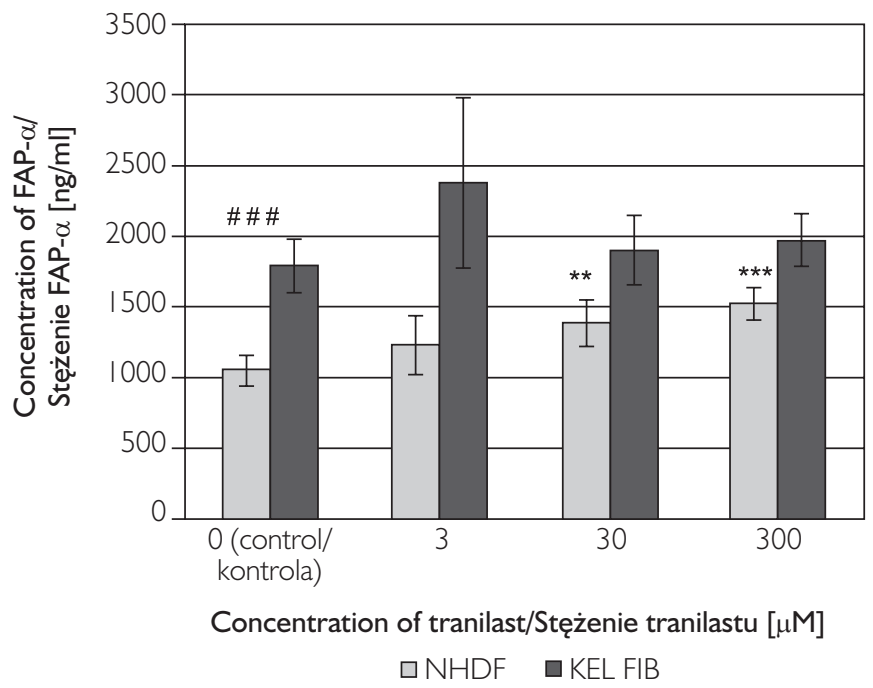

Figure 3. Results of FAP- $\alpha$ protein expression in normal and keloid fibroblasts treated with tranilast ( $t$ test: $\# \# p<0.00$ I; Dunnett's test: *** $<0.01 ;$ **** $<0.001$ )

Rycina 3. Wyniki ekspresji białka FAP-a w fibroblastach prawidłowych oraz fibroblastach pochodzących z keloidów poddanych działaniu tranilastu (test t-Studenta: ${ }^{\# \#} p<0,00$ I; test Dunnetta: ${ }^{* *} p<0,0$ I; ${ }^{* * * *} p<0,00$ I)

Suzawa et al. revealed that tranilast selective inhibition of collagen biosynthesis (type I and III) and fibroblast proliferation depends on the capacity of tranilast to inhibit TGF- $\beta 1$, interleukin $1 \beta$ (IL-1 $\beta$ ) and prostaglandin E2 (PGE2) secretion by inflammatory cells such as macrophages [3]. Tranilast also inhibited the release of TGF- $\beta 1$ from keloid fibroblasts [5].

In the study, we tried to find out if tranilast is able to modulate expression of the important protease FAP- $\alpha$ in keloid fibroblasts cultured in vitro. Normal dermal fibroblasts were used as control cells. We also examined tranilast's impact on normal and keloid fibroblasts' viability.

In the conditions of our experiment, tranilast at concentrations of $3 \mu \mathrm{M}, 30 \mu \mathrm{M}$ and $300 \mu \mathrm{M}$ significantly decreased the viability of normal fibroblasts $(76 \pm 6 \%, 79.1 \pm 13.8 \%$ and $62.3 \pm 6.3 \%)$. It decreased the viability of keloid fibroblasts at $30 \mu \mathrm{M}$ and $300 \mu \mathrm{M}(78.7 \pm 6.3 \%$ and $69.9 \pm 12 \%)$ but did not inhibit cell viability at a lower concentration.

In keloids, besides overproduction of dermal collagen and other fibroblast proteins, also disturbed ECM degradation is observed [11, 19, 20]. The FAP- $\alpha$, a member of the group II integral serine proteases, may play an important role in remodeling of ECM and the invasive properties of keloids. This kind of activity associated with FAP- $\alpha$ expression is observed in reactive stromal fibroblasts found in cancers and in many cancer cells. While the full enzymatic activity of FAP- $\alpha$ is still unknown, it is certain that FAP- $\alpha$ cleaves gelatin and partially degraded or denatured collagen type I and III [16, 21]. Dienus et al. revealed that inhibition of FAP- $\alpha$ and DPPIV reduced the increased

\section{OMÓWIENIE}

Tranilast należy do selektywnych inhibitorów syntezy kolagenu i jest wykorzystywany jako środek przeciwfibroproliferacyjny w leczeniu keloidów i blizn hipertroficznych. Mechanizm działania przeciwfibrotycznego tranilastu nie został jednak dokładnie poznany.

W badaniu Suzawa i wsp. wykazano, że selektywne hamowanie przez tranilast biosyntezy kolagenu (typu I i III) oraz proliferacji fibroblastów zależy od zdolności tranilastu do hamowania wydzielania TGF- $\beta 1$, interleukiny $1 \beta$ (IL-1 $\beta$ ) i prostaglandyny E2 (PGE2) przez komórki zapalne, np. makrofagi [3]. Potwierdzono też, że tranilast hamuje wydzielanie TGF- $\beta 1$ z fibroblastów keloidowych [5].

Celem badania było ustalenie, czy tranilast ma zdolność modulowania ekspresji proteazy FAP- $\alpha$ $\mathrm{w}$ keloidowych fibroblastach hodowanych in vitro. Jako komórki kontrolne wykorzystano prawidłowe fibroblasty skóry ludzkiej. Badaliśmy ponadto wpływ tranilastu na przeżywalność fibroblastów prawidłowych oraz keloidowych.

W badaniu tranilast w stężeniach $3 \mu \mathrm{M}, 30 \mu \mathrm{M}$ i $300 \mu \mathrm{M}$ istotnie redukował przeżywalność prawidłowych fibroblastów $(76 \pm 6 \%, 79,1 \pm 13,8 \%$ i $62,3 \pm 6,3 \%)$. Zmniejszał także przeżywalność fibroblastów keloidowych w stężeniach $30 \mu \mathrm{M}$ i $300 \mu \mathrm{M}(78,7 \pm 6,3 \%$ i 69,9 $\pm 12 \%)$. Przy mniejszym stężeniu leku nie stwierdzono natomiast identycznego działania.

Poza nadprodukcją kolagenu i innych białek w keloidach obserwuje się również zaburzenia rozkładu ECM $[11,19,20]$. Białko FAP- $\alpha$, zaliczane do grupy II integralnych proteaz serynowych, może odgrywać istotną rolę w przebudowie ECM oraz wpływać na właściwości inwazyjne keloidów. Ten rodzaj działa- 
invasiveness of keloid fibroblasts but had no effect on the synthesis of ECM and proinflammatory cytokines [19].

In the study, a greater number of FAP- $\alpha$ transcripts as well as higher concentration of FAP- $\alpha$ protein was found in keloid fibroblasts, in comparison to normal skin fibroblasts. These findings are consistent with previous reports that FAP- $\alpha$ presents increased expression in keloid fibroblasts [19].

However, the results of the present study indicate that tranilast at the tested concentrations did not affect the expression of FAP- $\alpha$ in keloid fibroblasts. Thus tranilast therapeutic action in the treatment of keloids cannot be linked to the effects of the drug on the expression of the enzyme in keloid fibroblasts. Instead the study revealed that tranilast stimulates the expression of FAP- $\alpha$ in normal fibroblasts. The data show that tranilast is a factor regulating the expression of FAP- $\alpha$ in normal fibroblasts. However, in keloid fibroblasts characterized by a chronic pathological phenotype, FAP- $\alpha$ is resistant to this agent. Different responsiveness of genes in normal and keloid fibroblasts to antifibrotic and proapoptotic factors was observed previously [22, 23]. Resistance to many kinds of therapies is also observed in other activated fibroblasts (e.g. tumor stromal fibroblasts mediate resistance to anti-angiogenic therapy) [24]. The molecular background of cells' acquisition of the pathological phenotype and its stable maintenance is still not known. The disturbed mechanism of regulation of gene expression in the cells is also poorly understood and has to be elucidated [24].

Our and other researchers' experiments [24] show that the phenotype of normal dermal fibroblasts cultured in vitro resembles a phenotype more like reactive fibroblasts of healing wounds than fibroblasts in healthy skin where FAP- $\alpha$ expression is not observed [21, 25-27]. We suspect that the effect of tranilast on keloid tissue degradation might result from its influence on enzymatic activity of fibroblasts surrounding keloids but not keloid fibroblasts. The presented hypothesis needs to be tested in future experiments. The stimulatory effect of tranilast on FAP- $\alpha$ expression in normal fibroblasts should also be extensively investigated in the aspect of wound healing. Since the factor upregulates the enzyme's expression in activated fibroblasts, tranilast treatment might be useful in the course of wound healing. It seems reasonable to undertake further research to improve knowledge of the drug's impact on the wound healing process.

Since tranilast action is not associated with inhibition of FAP- $\alpha$ in keloid fibroblasts, an additional study needs to be done to clarify its activity. Onshio et al. revealed that tranilast inhibits the nia związany z ekspresją FAP- $\alpha$ obserwuje się w reaktywnych fibroblastach stromy, które towarzyszą nowotworom i występują w wielu komórkach nowotworowych. Aktywność enzymatyczna FAP- $\alpha$ nie została dotychczas w pełni poznana, jednak wykazano, że FAP- $\alpha$ rozcina zdenaturowany kolagen i wywołuje częściowy rozkład lub denaturację kolagenu typu I i III $[16,21]$. W badaniu Dienus i wsp. odnotowano, że hamowanie FAP- $\alpha$ i DPPIV ogranicza wzmożoną inwazyjność fibroblastów keloidowych, lecz nie wpływa na syntezę ECM i cytokin prozapalnych [19].

Podczas badania większą liczbę transkryptów FAP- $\alpha$ oraz większe stężenie białka FAP- $\alpha$ stwierdzono w fibroblastach keloidowych niż w prawidłowych fibroblastach skóry ludzkiej. Wyniki te są spójne z wcześniejszymi doniesieniami, według których FAP- $\alpha$ wykazuje wzmożoną ekspresję w fibroblastach keloidowych [19].

Przedstawione wyniki wskazują jednak, że tranilast w badanych stężeniach nie wpływa na ekspresję FAP- $\alpha$ w fibroblastach keloidowych. Oznacza to, że działanie tranilastu w terapii keloidów nie wiąże się z wpływem leku na ekspresję enzymu w fibroblastach keloidowych. W badaniu wykazano natomiast, że tranilast pobudza ekspresję FAP- $\alpha$ w prawidłowych fibroblastach. A zatem jest czynnikiem regulującym ekspresję FAP- $\alpha$ w prawidłowych fibroblastach. Z kolei w fibroblastach keloidowych, które odznaczają się przewlekle patologicznym fenotypem, FAP- $\alpha$ wykazuje odporność na działanie tego leku. We wcześniejszych badaniach obserwowano różnice w odpowiedzi prawidłowych i keloidowych fibroblastów na czynniki przeciwfibrotyczne i proapoptotyczne [22, 23]. Oporność na wiele rodzajów leczenia stwierdza się także $\mathrm{w}$ innych aktywowanych fibroblastach (np. fibroblasty w stromie nowotworów pośredniczą w powstawaniu oporności na leczenie inhibitorami angiogenezy) [24]. Podłoże molekularne, które odpowiada za nabywanie przez komórki nieprawidłowego fenotypu i jego trwałe utrzymanie, jest nadal nieznane. Słabo poznany jest także mechanizm zaburzonej regulacji ekspresji genów w komórkach. Zagadnienie to wymaga dalszych badań [24].

Zarówno w przedstawionym badaniu, jak i w pracach innych autorów [24] wykazano, że fenotyp prawidłowych fibroblastów skóry ludzkiej hodowanych in vitro przypomina bardziej fenotyp reaktywnych fibroblastów typowych dla gojących się ran niż fibroblastów zdrowej skóry, w których nie obserwuje się ekspresji FAP- $\alpha$ [21, 25-27]. Przypuszczamy, że wpływ tranilastu na przebudowę tkanki keloidowej może wynikać z oddziaływania leku na aktywność enzymatyczną fibroblastów otaczających keloid, a nie bezpośrednio fibroblastów w obrębie keloidów. Przedstawiona hipoteza wymaga weryfikacji w dalszych badaniach. Szczegółowej analizy wymaga także wpływ tranilastu na stymulację ekspresji FAP- $\alpha$ $\mathrm{w}$ prawidłowych fibroblastach w zakresie gojenia ran. 
function of cancer-associated fibroblasts (CAFs) by inhibition of proliferation and reduction of the level of stromal cell-derived factor-1 (SDF-1), PGE2 and TGF- $\beta 1$. The authors also observed that the medium in which CAFs had been cultured in the presence of tranilast suppressed the induction of regulatory $\mathrm{T}$ cells and myeloid-derived suppressor cells (MDSC) from their progenitor cells [18]. Because CAFs exhibit a similar phenotype to keloid fibroblasts, we think that tranilast action might be similar in both cell types. Similarly to CAFs, keloid fibroblasts recruit mesenchymal stem cells and induce their differentiation, so we think that tranilast action in keloids might also involve this aspect of its biology [28].

Another interesting aspect of tranilast action in keloids is its possible influence on epithelial-mesenchymal interactions. Recent studies have noted the roles of keratinocytes in the pathogenesis of keloids [29, 30]. Hahn et al. demonstrated that keloid keratinocytes exhibit adhesion abnormalities and display a transcriptional signature reminiscent of cells undergoing epithelial-mesenchymal transition (EMT). A critical mediator in this process is TGF- $\beta 1$ [29], the factor whose expression is downregulated in many cells by tranilast $[1,31]$. In keloids, keratinocytes promote proliferation, inhibit apoptosis of the underlying fibroblasts and upregulate TGF- $\beta 1$ expression - the key regulator of fibrotic processes [30]. Kubo et al. revealed that tranilast inhibits growth of normal human keratinocytes and induces changes in cell morphology by downregulation of F-actin and vinculin in a dose-dependent manner. Consequently, tranilast decreases keratinocytes spreading and focal contact formation [32]. The inhibition of keloid keratinocytes' growth and their activity might be beneficial for the treatment of keloids. Since tranilast diminishes the activity of normal keratinocytes, it might also diminish keloid keratinocytes' growth and motility. Additional research needs to be done to shed light on the drug activity in keloid keratinocytes [29].

Another hypothesis, based on the reports of others, is that tranilast action in keloids is not direct but rather through modulation of cytokines released by inflammatory cells present in keloids. Keloid formation, similarly to hypertrophic scars, is a result of aberrant wound healing. Besides excessive collagen deposition, keloids characterize continuous, localized inflammation. Histological$1 y$, the reticular layer of keloids, besides increased numbers of fibroblasts, contains inflammatory cells and newly formed blood vessels [33]. Reduction of inflammation is one documented direction in keloid treatment. Shigeki revealed that iontophoresis of tranilast into affected parts of the skin led to re-
Ponieważ czynnik ten wzmaga ekspresję enzymów w aktywowanych fibroblastach, leczenie tranilastem może korzystnie wpływać na proces gojenia. Zasadne jest prowadzenie dalszych badań rozszerzających wiedzę na temat oddziaływania leku na gojenie ran.

Ponieważ działanie tranilastu nie wiąże się z hamowaniem FAP- $\alpha$ w fibroblastach keloidowych, niezbędne są kolejne badania, aby wyjaśnić mechanizm jego działania. W pracy Onshio i wsp. wykazano, że tranilast osłabia aktywność fibroblastów związanych z nowotworem (CAF) poprzez hamowanie proliferacji i obniżanie stężenia zrębowego czynnika wzrostu 1 (SDF-1), PGE2 i TGF- $\beta 1$. Autorzy zaobserwowali także, że podłoże, na którym hodowano CAF w obecności tranilastu, hamuje indukcję limfocytów T regulatorowych oraz komórek supresyjnych pochodzących z linii mieloidalnej (MDSC) z ich komórek progenitorowych [18]. Ponieważ CAF mają podobny fenotyp do fibroblastów keloidowych, uważamy, że wpływ tranilastu na oba te typy komórek może być podobny. Fibroblasty keloidowe, tak jak CAF, rekrutują mezechymalne komórki macierzyste i indukują proces ich różnicowania. Należy uznać, że działanie tranilastu $\mathrm{w}$ keloidach może obejmować również ten aspekt ich biologii [28].

Innym ciekawym zagadnieniem związanym z działaniem tranilastu w keloidach jest jego wpływ na oddziaływania nabłonkowo-mezenchymalne. W najnowszych badaniach zaobserwowano udział keratynocytów w patogenezie keloidów [29, 30]. Hahn i wsp. wykazali, że keratynocyty keloidowe charakteryzują się zaburzeniami adhezji i przypominają komórki przechodzące przemianę nabłonkowo-mezenchymalną (EMT). Krytycznym mediatorem $\mathrm{w}$ tym procesie jest TGF- $\beta 1$ [29] czynnik, którego ekspresja ulega osłabieniu w wielu komórkach pod wpływem tranilastu $[1,31]$. W keloidach keratynocyty pobudzają proliferację, hamują apoptozę fibroblastów, a także nasilają ekspresję TGF- $\beta 1$ - ważnego regulatora procesów włóknienia [30]. Kubo i wsp. wykazali, że tranilast hamuje wzrost prawidłowych ludzkich keratynocytów i wywołuje zmiany w morfologii komórek poprzez obniżenie regulacji F-aktyny i winkuliny w zależności od dawki. W efekcie tranilast ogranicza rozpłaszczanie się keratynocytów i powstawanie ognisk adhezji miejscowej (focal contact) [32]. W terapii keloidów korzystną rolę może odgrywać hamowanie wzrostu keratynocytów keloidowych oraz ich aktywności. Ponieważ tranilast osłabia aktywność prawidłowych keratynocytów, może również ograniczać wzrost i motorykę keratynocytów keloidowych. Niezbędne są dalsze badania, aby poszerzyć dostępną wiedzę o działaniu leku na keratynocyty keloidowe [29].

Według innej hipotezy, opartej na doniesieniach innych autorów, lek nie działa w obrębie keloidów bezpośrednio, ale poprzez modulację wydzielania cytokin przez komórki zapalne w keloidach. Rozwój keloidów 
lief of pain and itching after only one or two treatments. Reduction in redness - another symptom of inflammation - and partial flattening of keloid is observed after longer duration of therapy [34].

Previous studies indicated that tranilast, apart from TGF- $\beta$ inhibition [35], inhibits secretion of IL-6, IL-12, interferon $\gamma($ IFN- $\gamma$ ) [34] and monocyte 1 chemotactic protein (MCP-1) [36]. It also inhibits PGE2 synthesis [3] and antagonizes vascular endothelial growth factor (VEGF) action [37].

Shimizu et al. also revealed that tranilast not only influences cytokine production by inflammatory cells but also down regulates production of MMP-8, MMP-9 and TIMP-1 from activated neutrophils, thereby enhancing its migration and activity [38].

Unknown is ADAMs involvement in keloid formation. A recent study revealed that these enzymes play a role in various human cancers, where increased expression of ADAM-8, -9, -10, 15, -17, -19 and -28 is observed [39].

\section{CONCLUSIONS}

Regardless of tranilast's molecular mechanism of action in keloids, the drug exhibits high, documented potential in keloid treatment. At present, in keloid therapy the following are applied: surgical methods that reduce tension, radiotherapy, cryotherapy, compression therapy, and pharmacological therapy - 5-fluorouracil (5-FU) injection, verapamil, glucocorticosteroid injection/tape/ointment, bleomycin. However, none of them gives satisfactory results [11, 32]. Thus, the drug's incorporation in keloid therapy in Poland might improve the efficacy of currently applied therapies.

The aim of this publication was also to draw the attention of physicians to the positive side effects of many drugs. Initially, tranilast was identified as an anti-allergic agent and used in the treatment of inflammatory diseases. Suggestions for its use in treatment of keloids and hypertrophic scars were added later, after physicians' observation that keloid size decreases in patients with allergy treated with tranilast. Thereafter these observations were confirmed by investigators who revealed that tranilast inhibits the proliferation of fibroblasts and selectively suppresses collagen deposition.

\section{ACKNOWLEDGMENTS}

This research was supported by Medical University of Silesia grants KNW-1-012/P/1/0 and KNW2-006/N/4/N.
- podobnie jak blizn hipertroficznych - jest skutkiem nieprawidłowego procesu gojenia ran. Poza nadmiernym odkładaniem się kolagenu charakterystyczną cechą keloidów jest ciągły miejscowy stan zapalny. Z histologicznego punktu widzenia poza zwiększoną liczbą fibroblastów warstwa siateczkowa keloidów zawiera komórki zapalne i nowo powstałe naczynia krwionośne [33]. Łagodzenie stanu zapalnego jest jednym z potwierdzonych kierunków terapii keloidów. Shigeki i wsp. zaobserwowali, że jontoforeza z wykorzystaniem tranilastu bezpośrednio na zajęty obszar skóry łagodzi dolegliwości bólowe i świąd już po 1-2 zabiegach. Z kolei przy dłuższym leczeniu lek niweluje zaczerwienienie skóry i powoduje częściowe zmniejszenie wysokości keloidu [34].

Przeprowadzone dotychczas badania wykazują, że poza hamowaniem TGF- $\beta$ [35] tranilast blokuje także wydzielanie IL-6, IL-12, interferonu $\gamma$ (IFN- $\gamma$ ) [34] oraz białka chemotaktycznego monocytów 1 (MCP-1) [36]. Hamuje też syntezę PGE2 [3] oraz antagonizuje działanie czynnika wzrostu śródbłonka naczyniowego (VEGF) [37].

Shimizu i wsp. zaobserwowali również, że poza oddziaływaniem na wytwarzanie cytokin przez komórki zapalne tranilast osłabia wytwarzanie MMP-8, MMP-9 i TIMP-1 z aktywowanych neutrofilów, co nasila ich migrację i aktywność [38].

Nieznany jest udział metaloproteinaz ADAM w powstawaniu keloidów. W niedawno przeprowadzonym badaniu wykazano, że enzymy te odgrywają pewną rolę w wielu typach nowotworów u ludzi, w których obserwuje się wzmożoną ekspresję ADAM-8, -9, -10, -15, -17, -19 i -28 [39].

\section{WNIOSKI}

Niezależnie od molekularnego mechanizmu działania tranilastu w keloidach, lek ma potwierdzony wysoki potencjał w leczeniu tego schorzenia. Aktualnie w terapii keloidów stosuje się metody chirurgiczne obniżające wzmożone napięcie skóry, a także radioterapię, krioterapię, leczenie uciskowe oraz farmakologiczne 5-fluorouracyl (5-FU) w postaci iniekcji, werapamil, glikokortykosteroidy w postaci iniekcji, taśmy lub maści, bleomycynę. Żadna z tych metod nie daje jednak zadowalających wyników [11, 32]. Z tego powodu uwzględnienie tranilastu $\mathrm{w}$ terapii keloidów w Polsce może zwiększyć skuteczność obecnie stosowanych metod.

Jednym z celów niniejszej pracy było zwrócenie uwagi lekarzy na korzystne skutki uboczne wielu leków. Tranilast początkowo klasyfikowano jako lek przeciwalergiczny i stosowano w terapii chorób zapalnych. Sugestie, że może on być przydatny także w leczeniu keloidów i blizn hipertroficznych, pojawiły się dopiero później, gdy zaobserwowano zmniej- 


\section{CONFLICT OF INTEREST}

The authors declare no conflict of interest. szenie wielkości keloidów u pacjentów z alergiami leczonych tranilastem. Obserwacje te zostały następnie potwierdzone przez badaczy, którzy wykazali, że lek hamuje proliferację fibroblastów i selektywnie blokuje odkładanie się kolagenu.

\section{PODZIĘKOWANIA}

Badanie zrealizowano przy wsparciu Śląskiego Uniwersytetu Medycznego (granty nr KNW-1-012/P/1/0 i KNW-2-006/N/4/N).

\section{KONFLIKT INTERESÓW}

Autorzy deklarują brak konfliktu interesów.

\section{References}

\section{Piśmiennictwo}

1. Darakhshan S., Pour A.B.: Tranilast: a review of its therapeutic applications. Pharmacol Res 2015, 91, 15-28

2. Konneh M.: Tranilast, Kissei Pharmaceuticals. IDrugs 1998, 1, 141-146.

3. Suzawa H., Kikuchi S., Ichikawa K., Koda A.: Inhibitory action of tranilast, an anti-allergic drug, on the release of cytokines and PGE2 from human monocytes and macrophages. Jpn J Pharmacol 1992, 60, 85-90.

4. Yamada H., Tajima S., Nishikawa T., Murad S., Pinnel S.R.: Tranilast, a selective inhibitor of collagen synthesis in human skin fibroblasts. J Biochem 1994, 116, 892-897.

5. Suzawa H., Kikuchi S., Arai N., Koda A.: The mechanism involved in the inhibitory action of tranilast on collagen biosynthesis of keloid fibroblasts. Jpn J Pharmacol 1992, 60, 91-96.

6. Suzawa H., Kikuchi S., Ichikawa K., Arai N., Tazawa S., Tsuchiya O., et al.: Effect of tranilast, an anti-allergic drug, on the human keloid tissues. Nippon Yakurigaku Zasshi 1992, 99, 231-239.

7. Davidson S., Aziz N., Rashid R.M.. Khachemoune A.: A primary care perspective on keloids. Medscape J Med 2009, $11,1-18$.

8. Ogawa R.: Keloid and hypertrophic scars are the result of chronic inflammation in the reticular dermis. Int J Mol Sci 2017, 18 , E606.

9. Ulrich D., Ulrich F., Unglaub F., Piatkowski A., Pallua N.: Matrix metalloproteinases and tissue inhibitors of metalloproteinases in patients with different types of scars and keloids. J Plast Reconstr Aesthet Surg 2010, 63, 1015-1021.

10. Robles D.T., Moore E., Draznin M., Berg D.: Keloids: pathophysiology and management. Dermatol Online J $2007,13,9$.

11. Antończak P., Jurzak M., Adamczyk K., Garncarczyk A.: Wybrane molekularne aspekty procesu fibroproliferacyjnego w przebiegu keloidów. Przegl Dermatol 2015, 102, 253-262.

12. Shih B., Garside E., McGrouther D.A., Bayat A.: Molecular dissection of abnormal wound healing processes resulting in keloid disease. Wound Repair Regen 2010, 18, 139-153.

13. O'Brien P., O'Connor B.F.: Seprase: an overview of an important matrix serine protease. Biochim Biophys Acta 2008, 1784, 1130-1145.

14. Hamson E.J., Keane F.M., Tholen S., Schilling O., Gorrell M.D.: Understanding fibroblast activation protein (FAP): substrates, activities, expression and targeting for cancer therapy. Proteomics Clin Appl 2014, 8, 454-463.

15. Kelly T., Huang Y., Simms A.E., Mazur A.: Fibroblast activation protein-alpha: a key modulator of the microenvironment in multiple pathologies. Int Rev Cell Mol Biol 2012, 297, 83-116.

16. Jurzak M., Antończak P., Adamczyk K.: Białko aktywujące fibroblasty a (FAPa) - udział w gojeniu tkanek i kancerogenezie. Postep Biol Komorki 2011, 38, 547-713.

17. Shiga K., Hara M., Nagasaki T., Sato T., Takahashi H., Takeyama H.: Cancer-associated fibroblasts: their characteristics and their roles in tumor growth. Cancer 2015, 7, 2443-2458.

18. Ohshio Y., Hanaoka J., Kontani K., Teramoto K.: Tranilast inhibits the function of cancer-associated fibroblasts responsible for the induction of immune suppressor cell types. Scand J Immunol 2014, 80, 408-416.

19. Dienus K., Bayat A., Gilmore B.F., Seifert O.: Increased expression of fibroblast activation protein-alpha in keloid fibroblasts: implications for development of a novel treatment option. Arch Dermatol Res 2010, 302, 725-731.

20. Neely A.N., Clendening C.E., Gardner J., Greenhalgh D.G., Warden G.D.: Gelatinase activity in keloids and hypertrophic scars. Wound Repair Regen 1999, 7, 166-171.

21. Christiansen V.J., Jackson K.W., Lee K.N., McKee P.A.: Effect of fibroblast activation protein and alpha2-antiplasmin cleaving enzyme on collagen types I, III, and IV. Arch Biochem Biophys 2007, 457, 177-186.

22. Jurzak M., Adamczyk K.: Influence of genistein on C-Jun, C-Fos and Fos-B of AP-1 subunits expression in skin keratinocytes, fibroblasts and keloid fibroblasts cultured in vitro. Acta Pol Pharm 2013, 70, 205-213.

23. Ishihara H., Yoshimoto H., Fujioka M., Murakami R., Hirano A., Fujii T., et al.: Keloid fibroblasts resist ceramide-induced apoptosis by overexpression of insulin-like growth factor I receptor. J Invest Dermatol 2000, 115, 1065-1071.

24. Shimodo M., Mellody K.T., Orimo A.: Carcinoma-associated fibroblasts are rare-limiting determinant for tumour progression. Sem Cell Dev Biol 2010, 21, 19-25. 
25. Rettig W.J., Garin-Chesa P., Healey J.H., Su S.L., Ozer H.L., Schwab M., et al.: Regulation and heteromeric structure of the fibroblast activation protein in normal and transformed cells of mesenchymal and neuroectodermal origin. Cancer Res 1993, 53, 3327-3335.

26. Monsky W.L., Lin C.Y., Aoyama A., Kelly T., Akiyama S.K., Mueller S.C., et al.: A potential marker protease of invasiveness, seprase, is localized on invadopodia of human malignant melanoma cells. Cancer Res 1994, 54, 5702-5710.

27. Aoyama A., Chen W.T.: A 170-kDa membrane-bound protease is associated with the expression of invasiveness by human malignant melanoma cells. Proc Natl Acad Sci U S A 1990, 87, 8296-8300.

28. Arias J., Aller M.A., Arias J.I.: Surgical inflammation. [In:] M.A. Aller, M.P. de Miguel, C. Jiménez, S. Fuentes-Julián, A. Manrique, A. Blázquez-Martínez, et al.: Mesenchymal Stem Cells: Advances and Surgical Applications. Bentham Science 2013, 27, 250-276.

29. Hahn J.M., McFarland K.L., Combs K.A., Supp D.M.: Partial epithelial-mesenchymal transition in keloid scars: regulation of keloid keratinocyte gene expression by transforming growth factor-beta1. Burns Trauma 2016, 4, 30.

30. Funayama E., Chodon T., Oyama A., Sugihara T.: Keratinocytes promote proliferation and inhibit apoptosis of the underlying fibroblast: an important role in the pathogenesis of keloid. J Invest Dermatol 2003, 121, 1326-1331.

31. Uno M., Kurita S., Misu H., Ando H., Ota T., Matsuzawa-Nagata N., et al.: Tranilast, an antifibrogenic agent, ameliorates a dietary rat model of nonalcoholic steatohepatitis. Hepatology 2008, 48, 109-118.

32. Kubo M., Zhao Y., Moriguchi T.: Tranilast inhibits the cell growth of normal human keratinocytes in vitro. Arch Dermatol Res 2012, 304, 745-753.

33. Ogawa R.: Keloid and hypertrophic scars are results of chronic inflammation in the reticular dermis. Int J Mol Sci 2017, 18, E606.

34. Shigeki S., Murakami T., Yata N., Ikuta Y.: Treatment of keloid and hypertrophic scars by iontophoretic transdermal delivery of tranilast. Scand J Plast Reconstr Hand Surg 1997, 31, 151-158.

35. Prud'homme G.J.: Pathobiology of transforming growth factor beta in cancer, fibrosis and immunologic disease, and therapeutic considerations. Lab Invest 2007, 87, 1077-1091.

36. Chikaraishi A., Hirahashi J., Takase O., Marumo T., Hishikawa K., Hayashi M., et al.: Tranilast inhibits interleukin- 1betainduced monocyte chemoattractant protein-1 expression in rat mesangial cells. Eur J Pharmacol 2001, 427, 151-158.

37. Isaji M., Miyata H., Ajisawa Y., Yoshimura N.: Inhibition by tranilast of vascular endothelial growth factor (VEGF)/vascular permeability factor (VPF)-induced increase in vascular permeability in rats. Life Sci 1998, 63, 71-74.

38. Shimizu T., Kanai K.I., Kyo Y., Asano K., Hisamitsu T., Suzaki H.: Effect of tranilast on matrix metalloproteinase production from neutrophils in-vitro. J Pharm Pharmacol 2006, 58, 91-99.

39. Giebeler N., Zigrino P.: A disintegrin and metalloprotease (ADAM): historical overview of their functions. Toxins $2016,8,122$.

Received: 24.11 .2016

Accepted: 24.05.2017

Otrzymano: 24.11.2016 r.

Zaakceptowano: 24.05 .2017 r.

How to cite this article

Antończak P.P., Jurzak M., Adamczyk K., Garncarczyk A., Hartman-Petrycka M.: The effect of tranilast on fibroblast activation protein $\alpha$ (FAP- $\alpha$ ) expression in normal and keloid fibroblasts in vitro. Dermatol Rev/Przegl Dermatol 2017, $104,300-313$. DOI: https://doi.org/10.5114/dr.2017.68777. 